\title{
Resilien Pengusaha Bas Awam dalam Hadapi Tempoh Pandemik COVID-19
}

\section{(Resilience of Public Bus Operators During The COVID-19 Pandemic)}

\author{
Hazlee Jirip ${ }^{1}$ (D) Harifah Mohd Noor²*iD \\ 1Pusat Pengajian Pascasiswazah, Universiti Malaysia Sabah (UMS), Sabah, Malaysia. \\ Email: hazleejirip97@gmail.com \\ ${ }^{2}$ Fakulti Sains Sosial dan Kemanusiaan, Universiti Malaysia Sabah (UMS), Sabah, Malaysia. \\ Email: harifah@ums.edu.my
}

\section{CORRESPONDING \\ AUTHOR (*): \\ Harifah Mohd Noor \\ (harifah@ums.edu.my) \\ KATA KUNCI: \\ Resilien \\ Pengusaha bas awam \\ Pengangkutan awam \\ Covid-19 \\ Perintah kawalan pergerakan}

\section{KEYWORDS:}

Resilient

Public bus operator

Public transportation

Covid-19

Movement control order

\section{CITATION:}

Hazlee Jirip \& Harifah Mohd Noor. (2022).

Resilien Pengusaha Bas Awam dalam

Hadapi Tempoh Pandemik COVID-19.

Malaysian Journal of Social Sciences and

Humanities (MJSSH), 7(2), e001305.

https://doi.org/10.47405/mjssh.v7i2.1305

\begin{abstract}
ABSTRAK
Resilien merupakan kemampuan untuk menyesuaikan diri dan mengatasi tekanan dalaman mahupun luaran dalam satu tempoh yang sukar. Dalam tempoh pandemik ini, kesukaran untuk menjalankan perkhidmatan pengangkutan awam menjadi satu cabaran yang besar khususnya dalam kalangan pengusaha bas. Penularan penyakit pandemik Covid-19 telah memaksa kerajaan di kebanyakan negara, di seluruh dunia untuk melaksanakan sekatan pergerakan (lockdown) bagi mengelakkan penularan Covid-19 berlaku di negara masing-masing. Pelaksanaan sekatan pergerakan yang dilakukan memberikan impak yang besar terhadap penurunan penggunaan perkhidmatan pengangkutan awam. Selain itu, penularan Covid-19 juga telah mengakibatkan pengusaha bas mengalami penurunan kadar aliran tunai. Oleh itu, kajian ini bertujuan mengenal pasti usaha pengusaha bas awam dalam menangani dan meneruskan kelangsungan perkhidmatan dalam tempoh pandemik Covid-19. Penggunaan terhadap sumber sekunder diaplikasikan dalam kajian ini dengan menyelidik kajian-kajian lepas seperti jurnal, buku, artikel dan laporan untuk membincangkan konsep resilien pengusaha bas awam dalam tempoh pandemik ini.
\end{abstract}

\section{ABSTRACT}

Resilience is the ability to adapt and cope with both internal and external pressures at this difficult time. During this pandemic period, the challenge of managing public transportation services has become a major one, particularly for bus operators. The spread of Covid-19 disease has forced governments in most countries around the world to impose movement control order (lockdown) to prevent the spread of Covid-19 from occurring in their home countries. The implementation of movement restrictions has had a significant impact on the diminishing use of public transport services. In addition, the spread of Covid-19 has also led to lower cash rates for bus operators. 
Therefore, the purpose of this study is to determine the efforts of public bus operators to manage and maintain service continuity during the Covid-19 pandemic. The use of secondary sources is applied in this study by searching for the previous studies such as journals, books, articles and reports to discuss the concept of resilience of public bus operators during this pandemic period.

Sumbangan/Keaslian: Kajian ini menyumbang kepada literatur sedia ada, namun demikian ia turut memberikan sumbangan terhadap literatur yang terkini iaitu, model resilien yang diubah suai daripada model-model sedia ada adalah sesuatu yang baru daripada penulisan kajian yang lepas. Ini kerana, model ini membincangkan resilien sistem pengangkutan dalam tempoh pandemik covid-19 yang berlaku pada ketika ini.

\section{Pengenalan}

Pengusaha bas awam dalam menghadapi cabaran penularan penyakit pandemik Covid19 yang berlaku di seluruh dunia adalah antara aspek yang penting untuk dinilai pada ketika ini. Penularan penyakit Covid-19 yang berlaku pada akhir Disember 2019, yang disahkan bermula di wilayah Wuhan, China (Zhu et al., 2020) menyebabkan sistem pengangkutan awam tidak dapat beroperasi akibat pelaksanaan sekatan pergerakan atau lockdown di kebanyakan negara di seluruh dunia. Pelaksanaan sekatan pergerakan adalah bertujuan untuk mengelakkan berlakunya penularan virus ini dengan pantas dalam kalangan penduduk negara masing-masing. Keadaan ini memberikan impak yang besar terhadap kelangsungan perkhidmatan bas awam yang mana kebanyakan pengguna perkhidmatan pengangkutan awam beralih kepada pengangkutan sendiri seperti kenderaan persendirian, motosikal, basikal mahupun berjalan kaki.

Tekanan yang semakin tinggi berlaku kepada pengusaha bas awam, menyebabkan golongan ini terpaksa mencari kaedah yang sesuai untuk mengelakkan mereka daripada terbelenggu dengan penurunan kadar aliran tunai yang mengakibatkan kualiti hidup pengusaha bas awam menurun. Kaedah atau usaha yang dilakukan dalam menghadapi cabaran dalam tempoh pandemik ini melibatkan beberapa pihak seperti individu itu sendiri, keluarga, masyarakat dan kerajaan di sesebuah negara. Kerajaan memainkan peranan yang besar terhadap kemampuan (resilien) pengusaha bas awam untuk terus bertahan dalam tempoh pandemik ini. Selain itu, pengusaha dan masyarakat juga memainkan peranan yang penting untuk memastikan resilien pengusaha bas awam dapat diteruskan.

Resilien adalah merujuk kepada ketahanan individu dalam menghadapi sesuatu masalah atau masa yang sukar dalam tempoh yang lama mahupun sebaliknya. Resilien juga dikaitkan dengan bagaimana cara seseorang individu untuk bangkit kembali daripada kesulitan dan kekecewaan (frustration) (Ledesma, 2014). Selain itu, resilien turut dapat diterangkan melalui maksud, sesebuah proses adaptasi dengan pengalaman hidup dalam tempoh yang sukar terutamanya melalui mental, emosi dan perilaku yang sentiasa fleksibel dengan keadaan semasa dengan cara penyesuaian diri dari sudut dalaman dan luaran. Manakala Keye dan Pidgeon (2013) menyatakan bahawa resilien adalah kemampuan untuk mempertahankan kestabilan psikologi dalam menghadapi tekanan. 
Dalam kajian ini, terdapat beberapa objektif dan matlamat kajian yang ditetapkan untuk dibincangkan dalam penulisan ini, pertama adalah perbincangan mengenai konsep pengusaha bas awam. Seterusnya adalah, memfokuskan terhadap perbincangan konsep resilien serta model resilien. Manakala objektif yang terakhir adalah berkaitan dengan usaha atau kaedah yang dilakukan termasuklah individu, syarikat (pihak berkepentingan) dan kerajaan dalam memastikan daya tahan atau resilien pengusaha bas awam berterusan dan mampu mengadaptasi keadaan semasa untuk terus beroperasi dalam tempoh pandemik.

\section{Metod Kajian}

Kajian ini menggunakan kaedah analisis kandungan atau content analysis untuk mendapatkan maklumat serta data daripada kajian-kajian lepas yang berkaitan dengan resilien pengusaha bas awam semasa pandemik Covid-19. Kaedah analisis kandungan adalah teknik untuk membuat kesimpulan daripada maklumat yang diperolehi melalui kajian lepas dengan mengenal pasti ciri-ciri maklumat yang dikehendaki dan ditentukan secara sistematik dan berobjektif (Prasad, 2008). Menurut Sabitha Marican (2009), antara data sekunder yang digunakan dalam sesuatu kajian yang menggunakan sumber sekunder adalah seperti tesis, laporan, buku dan artikel atau jurnal. Selain itu, terdapat beberapa fasa yang penting dalam proses menyorot kajian lepas, bagi memastikan kajian ini dapat dijalankan dengan baik. Proses tersebut adalah, memastikan artikel yang dirujuk mempunyai kaitan dengan kajian yang dijalankan dengan menilai dan menyaring setiap artikel berdasarkan isu yang hendak dikaji. Setelah itu, artikel yang dianggap bersesuaian dengan isu kajian akan disorot serta dianalisis untuk penulisan kajian ini.

\section{Teori dan Konsep Resilien}

Teori dan konsep resilien adalah berbeza mengikut bidang disiplin masing-masing. Banyak kajian yang telah dilakukan mengenai teori dan konsep resilien namun terdapat persamaan diantara konsep yang digunakan mengikut bidang iaitu mengenai pengertian resilien tersebut. Jadual 1 merupakan konsep resilien mengikut bidang yang dinyatakan oleh sarjana-sarjana lepas. Oleh itu, dapat disimpulkan bahawa persamaan di antara teori dan konsep resilien dari pelbagai bidang disiplin adalah proses kebangkitan serta ketahanan sama ada individu, masyarakat dan organisasi (sistem) untuk menghadapi sesuatu masalah dalam suatu tempoh, sama ada tempoh yang lama mahupun dalam tempoh yang singkat. Selain itu, resilien turut memberikan maksud iaitu, bagaimana individu, masyarakat atau sesebuah organisasi itu beradaptasi dengan keadaan semasa dan menyesuaikan keadaan bagi tujuan meneruskan kebiasaan (aktiviti) yang dilakukan walaupun menghadapi sebuah perubahan atau tekanan.

Jadual 1: Konsep Resilien

\begin{tabular}{lll}
\hline Sarjana & $\begin{array}{l}\text { Bidang } \\
\text { Disiplin }\end{array}$ & Kata Kunci \\
\hline Holling (1973) & Ekologi & $\begin{array}{l}\text { Memungkinkan sistem menyerap perubahan dan } \\
\text { bertahan. }\end{array}$ \\
Adger (2000) & $\begin{array}{l}\text { Ekologi } \\
\text { Manusia }\end{array}$ & $\begin{array}{l}\text { Kemampuan kumpulan atau masyarakat untuk } \\
\text { mengatasi tekanan dan gangguan luaran akibat } \\
\text { perubahan sosial, politik dan persekitaran. }\end{array}$ \\
\hline
\end{tabular}




\begin{tabular}{|c|c|c|}
\hline $\begin{array}{l}\text { Hollnagel et al. } \\
\text { (2006) }\end{array}$ & Kejuruteraan & $\begin{array}{l}\text { Kemampuan organisasi (sistem) untuk } \\
\text { mempertahankan atau pulih dengan cepat kepada } \\
\text { keadaan stabil. } \\
\text { Dapat menyesuaikan fungsi serta bangkit sama ada } \\
\text { sebelum dan semasa, mengikut perubahan serta } \\
\text { gangguan sehingga dapat beroperasi seperti sedia } \\
\text { kala setelah gangguan atau masalah yang besar } \\
\text { serta tekanan yang berterusan berlaku. }\end{array}$ \\
\hline Zhang \& Lin (2010) & $\begin{array}{l}\text { Perusahaan } \\
\text { (Enterprise) }\end{array}$ & $\begin{array}{l}\text { Kemampuan dan bagaimana (cara) sistem terus } \\
\text { dapat berfungsi ke tahap yang diinginkan ketika } \\
\text { sistem mengalami kerosakan atau gangguan. }\end{array}$ \\
\hline $\begin{array}{l}\text { Zhang \& Van } \\
\text { (2011) }\end{array}$ & $\begin{array}{l}\text { Kejuruteraan } \\
\text { Pembuatan }\end{array}$ & $\begin{array}{l}\text { Kemampuan untuk memulihkan fungsi setelah } \\
\text { mengalami kegagalan daripada sebahagian sistem. }\end{array}$ \\
\hline Ledesma (2014) & Kepimpinan & $\begin{array}{l}\text { Kemampuan untuk bangkit dari kesukaran, } \\
\text { kekecewaan, dan kemalangan atau insiden yang } \\
\text { berlaku kepada seseorang individu ataupun } \\
\text { pemimpin. }\end{array}$ \\
\hline Turner (2014) & Kejururawatan & $\begin{array}{l}\text { Kemampuan untuk kembali kepada keadaan } \\
\text { normal atau "bangkit kembali" daripada kesukaran } \\
\text { atau trauma dan tetap fokus dan optimis terhadap } \\
\text { masa depan. }\end{array}$ \\
\hline Ganin et al. (2017) & $\begin{array}{l}\text { Kejuruteraan } \\
\text { Pengangkutan }\end{array}$ & Pemulihan sistem dari gangguan tambahan. \\
\hline $\begin{array}{l}\text { Noraini et al. } \\
(2018)\end{array}$ & $\begin{array}{l}\text { Kejuruteraan } \\
\text { Teknologi }\end{array}$ & $\begin{array}{l}\text { Pengembangan kemampuan atau keupayaan untuk } \\
\text { bangkit kembali lebih baik selepas bencana atau } \\
\text { insiden. }\end{array}$ \\
\hline
\end{tabular}

Lanjutan itu, berdasarkan Rajah 1 terdapat tiga model resilien yang digunakan oleh penyelidik-penyelidik lepas dalam menerangkan konsep resilien, namun pada dasarnya ia adalah menggambarkan mekanisme yang sama iaitu untuk menyerap tekanan atau perubahan dan penyesuaian kualiti berdasarkan keadaan semasa.

Rajah 1: Model Resilien

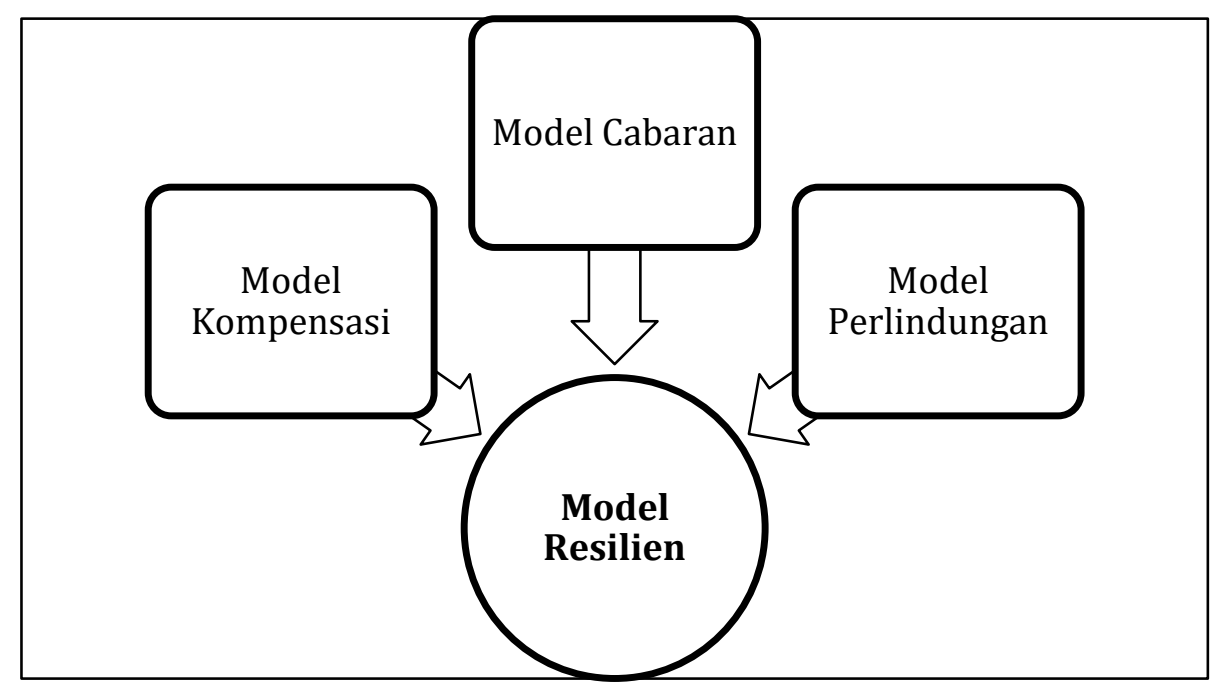

Sumber: O'Leary (1998)

Model kompensasi atau compensatory model adalah berkaitan dengan bagaimana kaedah seseorang individu menyesuaikan diri dengan keadaan yang memberikan 
tekanan dalam sesuatu tempoh. Model kompensasi adalah menjelaskan keadaan di mana faktor ketahanan bertindak balas atau beroperasi dalam arah yang bertentangan dengan faktor risiko. Selain itu, faktor ketahanan juga mempunyai kesan langsung terhadap hasil yang tidak bergantung kepada pengaruh faktor risiko (Fleming \& Ledogar, 2008). Tambahan itu, Werner dan Smith (2001), turut menyatakan empat ciri utama yang menggambarkan seseorang itu mempunyai daya ketahanan (resilien) yang baik iaitu, mempunyai pendekatan yang aktif untuk menyelesaikan masalah, kedua adalah mempunyai keinginan atau kecenderungan untuk merasakan pengalaman dalam keadaan yang positif walaupun ketika dalam tekanan atau masalah, ketiga kemampuan untuk berada di sekeliling individu yang positif dan keempat adalah mempunyai nilai diri dan kepercayaan yang kuat terhadap iman untuk sentiasa berada dalam keadaan yang positif.

Manakala bagi model cabaran atau challenge model pula, model ini berkait rapat diantara faktor risiko dan hasil sesuatu tindakan yang dilakukan. Di mana, hubungan antara faktor risiko dan hasilnya adalah 'curvilinear' yang bererti peningkatan nilai pada satu pemboleh ubah dihubungkaitkan dengan peningkatan atau penurunan dalam pemboleh ubah yang lain. Dengan erti kata yang lain, pendedahan kepada tahap risiko rendah dan tinggi mempunyai kaitan dengan hasil yang negatif namun pendedahan terhadap risiko yang sederhana akan memberikan impak sama ada negatif mahupun positif (Fleming \& Ledogar, 2008). Selain itu, O’Leary (1998) turut menyatakan bahawa model cabaran adalah menunjukkan risiko yang tidak terlalu ekstrem sebenarnya dapat meningkatkan penyesuaian diri seseorang terhadap sesuatu fenomena yang luar daripada kebiasaan.

Selain itu, model perlindungan atau protective model adalah suatu interaksi di antara faktor perlindungan dan faktor risiko yang mengurangkan kebarangkalian hasil negatif dan mengurangkan kesan pendedahan kepada risiko (O'Leary, 1998). Selain itu, model ini turut menjelaskan bahawa aset atau sumber daya menjadi sederhana atau mengurangkan kesan risiko terhadap impak yang negatif. Model protective juga boleh beroperasi dalam beberapa cara iaitu dapat meneutralkan kesan risiko dengan cara mengurangkan suatu pendedahan risiko tapi tidak membuang secara langsung risiko tersebut atau meningkatkan kesan positif dengan cara mencuba mencari jalan penyelesaian yang lain untuk mendapat impak yang lebih baik (Fleming \& Ledogar, 2008).

\subsection{Konsep Pengusaha Bas Awam}

Konsep pengusaha bas awam masih kurang dibincangkan di kalangan sarjana-sarjana yang lepas berbanding dengan konsep pengangkutan awam yang telah banyak dibahaskan dalam penulisan artikel mahupun jurnal. Jadual 2 merupakan konsep bas awam mengikut pernyataan sarjana-sarjana lepas.

\section{Jadual 2: Konsep Bas Awam}

\begin{tabular}{ll}
\hline Sarjana & Kata Kunci \\
\hline Andaleeb et al. & Memberikan perkhidmatan kepada penduduk bandar yang tidak \\
(2007) & $\begin{array}{l}\text { memiliki kereta persendirian dan tidak dapat membayar tambang teksi } \\
\text { dengan kerap. }\end{array}$ \\
Ali (2010) & $\begin{array}{l}\text { Perkhidmatan pengangkutan bas awam mempunyai kesan langsung } \\
\text { terhadap ekonomi negara. }\end{array}$ \\
\hline
\end{tabular}


Taylor \& Fink

(2013)

Litman (2010)

Harifah et al. (2016)
Untuk memindahkan sejumlah besar penumpang, dari satu lokasi ke lokasi lain, terutama di pusat bandar yang berpenduduk padat. Menjadi alat dasar yang berkesan untuk mengurangkan jumlah kereta dan kesesakan lalu lintas di jalan bandar.

Bas awam adalah salah satu daripada sistem pengangkutan awam darat yang terdiri daripada bas berhenti-henti, bas sewa, bas ekspres dan bas mini.

Walau bagaimana, terdapat juga sarjana-sarjana lepas yang memberikan pandangan atau mentafsirkan konsep pengusaha pengangkutan awam, walaupun begitu ianya tidak memberikan maksud secara terus terhadap konsep pengusaha bas awam, namun konsep tersebut saling berkaitan diantara satu sama lain. Hal ini kerana, pengangkutan bas awam merupakan salah satu daripada sistem pengangkutan awam darat. Jadual 3 merupakan definisi bagi pengusaha perkhidmatan awam.

\section{Jadual 3: Konsep Pengusaha (Operator) Perkhidmatan Awam}

\begin{tabular}{ll}
\hline Sarjana & Kata Kunci \\
\hline $\begin{array}{l}\text { Roy \& Yvrande- } \\
\text { Billon (2007) }\end{array}$ & $\begin{array}{l}\text { Syarikat pengangkutan awam mempunyai pelbagai kewajiban bagi } \\
\text { menyediakan perkhidmatan kepada masyarakat dimana syarikat } \\
\text { menetapkan harga yang sesuai untuk memastikan akses yang berpatutan } \\
\text { kepada semua penumpang. }\end{array}$ \\
Fatih et al. (2019) & $\begin{array}{l}\text { Menyediakan perkhidmatan pengangkutan awam dengan cara } \\
\text { menjimatkan kos dan meningkatkan kualiti atau keberkesanan } \\
\text { perkhidmatan. }\end{array}$ \\
Juan \& Patricia & $\begin{array}{l}\text { Syarikat swasta mengendalikan sistem pengangkutan awam berdasarkan } \\
\text { kontrak konsesi yang diberikan oleh kerajaan tempatan. }\end{array}$ \\
$\begin{array}{l}\text { McTigue et al. } \\
\text { (2020) }\end{array}$ & $\begin{array}{l}\text { Syarikat swasta bertanggungjawab untuk menentukan laluan, frekuensi, } \\
\text { kadar tambang, jenis tiket, jenis kenderaan dan penyediaan } \\
\text { perkhidmatan pelanggan. }\end{array}$ \\
Mohit Dev \& & $\begin{array}{l}\text { Pengangkutan awam adalah disediakan oleh institusi milik kerajaan atau } \\
\text { oleh institusi swasta. }\end{array}$ \\
(2020) &
\end{tabular}

Oleh itu, berdasarkan pernyataan sarjana lepas dapat diertikan bahawa, pengusaha bas awam adalah sebuah organisasi sama ada sebuah badan kerajaan atau syarikat swasta yang mengendalikan dan menyediakan perkhidmatan bas awam kepada masyarakat bandar bagi tujuan mengurangkan kesesakan jalan raya dan meningkatkan aksesibiliti warga kota. Bas awam adalah terdiri daripada bas mini, bas berhenti-henti dan bas sewa yang dioperasikan oleh syarikat swasta, persendirian atau kerajaan tempatan di sesebuah tempat seperti sebuah bandar raya. Selain itu, peningkatan kepada kualiti perkhidmatan pengangkutan bas awam turut memberikan impak yang signifikan terhadap peningkatan kualiti hidup penduduk setempat. Tambahan itu, penyediaan dan pengoperasian perkhidmatan bas awam turut menyumbang kepada peningkatan ekonomi sesebuah negara melalui peningkatan Keluaran Dalam Negara Kasar (KDNK) atau Gross domestic product (GDP).

\subsection{Resilien Dalam Sistem Pengangkutan}

Dalam konteks sistem pengangkutan, resilien adalah bertujuan untuk menilai parameter yang memastikan kemampuan sistem untuk beroperasi pada tahap yang tertentu sama ada dalam keadaan normal mahupun keadaan yang berada dalam luar jangkaan. Jika berlakunya kejadian yang tidak dijangka seperti bencana alam contohnya penularan 
penyakit pandemik, sistem resilien akan bertindak balas untuk mendapatkan keseimbangan dan seterusnya mampu beroperasi secara normal (Tamvakis \& Xenidis, 2012).

Selain itu, Nemeth (2008) menyatakan bahawa sistem resilien pengangkutan adalah merupakan aspek yang penting untuk bertindak balas terhadap permintaan mengikut keadaan semasa. Beliau turut menyatakan bahawa, pengukuran keupayaan sistem pengangkutan untuk bertindak balas dapat dinilai apabila keadaan perkhidmatan mendapat permintaan normal dan meningkat secara tiba-tiba serta ketika situasi penstrukturan sistem yang dilakukan semasa perkhidmatan beroperasi secara normal yang diperlukan untuk meningkatkan kualiti bagi menghadapi perubahan baru dan keadaan yang tidak dijangka.

Sebuah sistem pengangkutan dapat berfungsi melalui komponen iaitu komponen dalaman dan komponen luaran. Sistem ini adalah aspek yang penting untuk bertindak balas dalam sesuatu keadaan yang tidak dijangka. Komponen luaran dan dalaman mempunyai sub sistem yang beroperasi serta saling keterbergantungan antara satu dengan yang lain untuk melengkapkan sebuah sistem pengangkutan yang efisien. Komponen ini merupakan sistem yang bertindak balas semasa penilaian resilien dilakukan. Rajah 2 menyatakan dua komponen dan sub sistem yang mengerakkan sebuah sistem pengangkutan.

Rajah 2: Komponen Dalam Sistem Pengangkutan

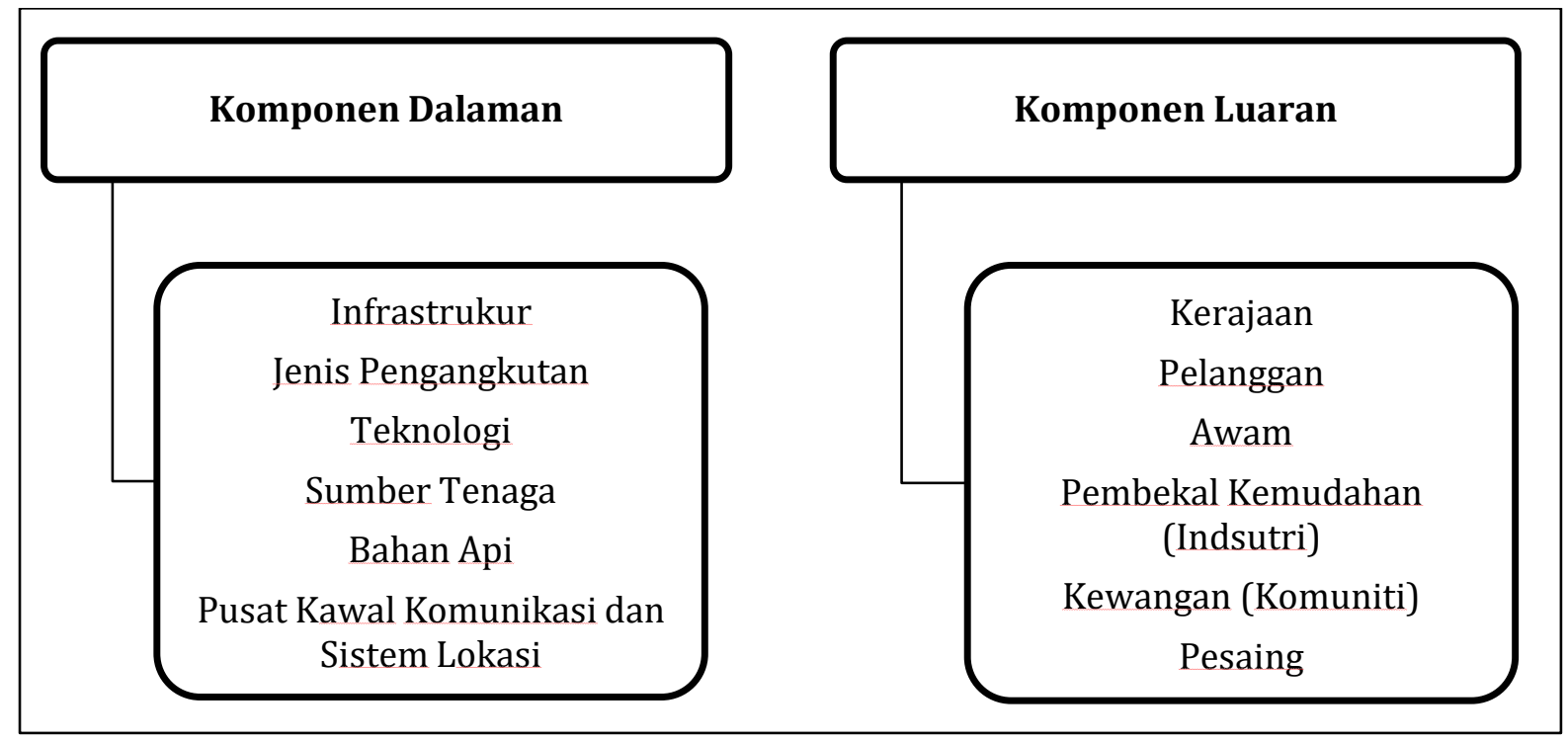

Sumber: Diubahsuai daripada Tamvakis dan Xenidis (2012)

Tekanan dalam sesebuah sistem pengangkutan mengakibatkan berlakunya perubahan yang tidak dijangka dalam suatu tempoh yang lama mahupun sementara. Rajah 3 menggambarkan proses penilaian resilien dalam sistem pengangkutan dalam satu tempoh yang sukar seperti tempoh penularan penyakit pandemik Covid-19 yang berlaku pada ketika ini. Proses penilaian ini berlaku apabila satu pemboleh ubah menghadapi tekanan yang rendah atau tinggi yang mana proses resilien akan berlaku setelah penilaian dilakukan. 
Rajah 3: Model Penilaian Resilien Sistem Pengangkutan

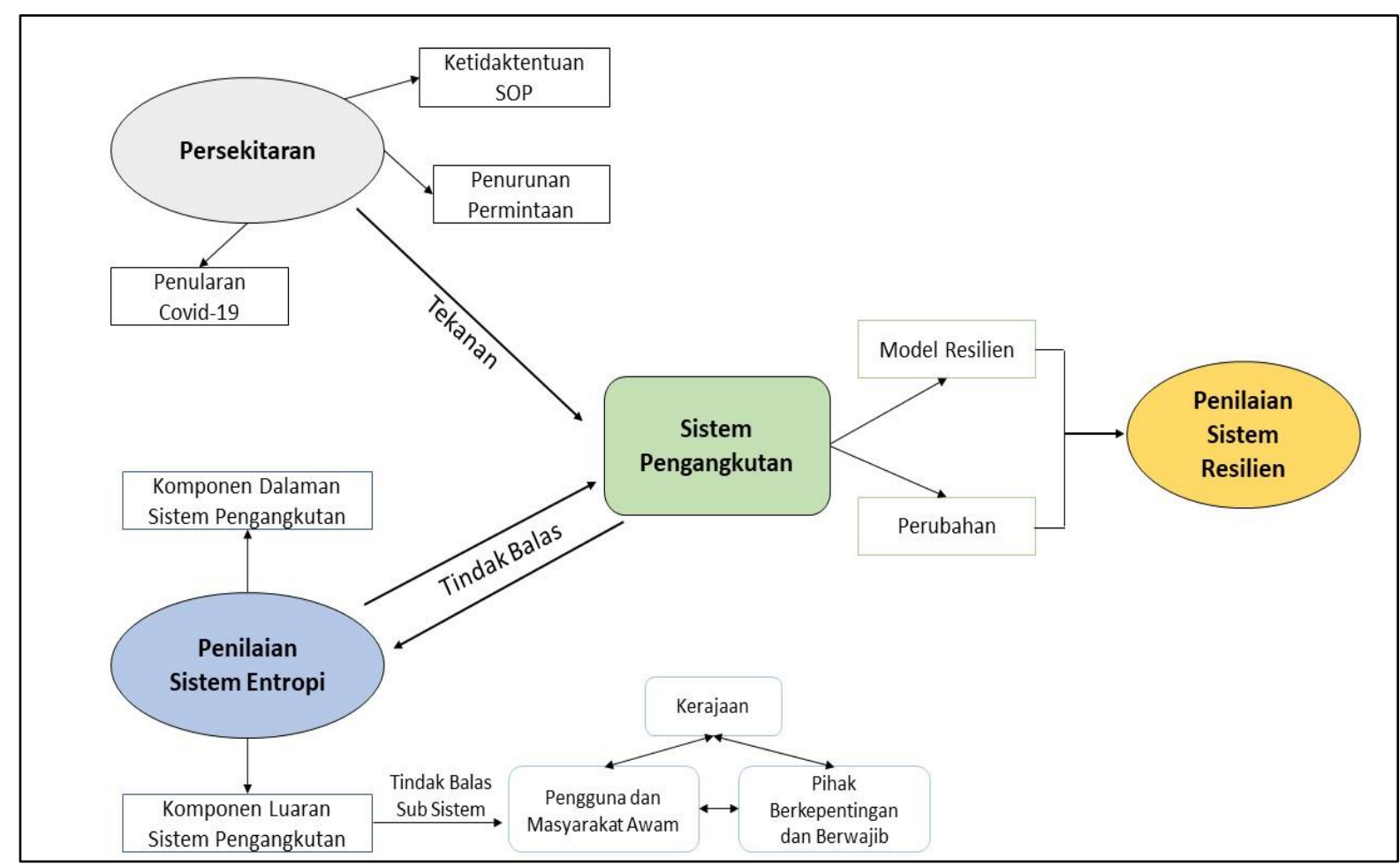

Sumber: Diubah suai daripada model Kenneth (1990) serta Tamvakis dan Xenidis (2012)

Dalam proses penilaian pertama, pemboleh ubah persekitaran akan dinilai untuk melihat apakah tekanan yang berlaku dalam pemboleh ubah tersebut yang mengakibatkan wujudnya tekanan terhadap sistem pengangkutan. Dalam tempoh ini, tekanan yang berlaku dalam sistem pengangkutan adalah impak daripada penularan covid-19 yang berlaku di seluruh dunia. Penularan ini menyebabkan pelaksanaan Prosedur Operasi Standard (SOP) yang mengakibatkan kesukaran pengoperasian dalam sistem pengangkutan awam. Keadaan ini menyebabkan penurunan permintaan perkhidmatan pengangkutan awam. Misalnya Molloy et al. (2020) menyatakan bahawa penggunaan perkhidmatan pengangkutan awam seperti kereta api, trem dan bus menurun secara mendadak di Switzerland. Keadaan ini memberikan tekanan kepada sistem pengangkutan dan perlu dinilai bagi mengatasi perkara ini.

Lanjutan daripada itu, sistem pengangkutan akan bertindak balas dengan setiap komponen yang ada melalui penilaian sistem entropi. Penilaian ini melibatkan keduadua komponen iaitu luaran dan dalaman bagi melihat apakah perubahan yang sesuai untuk dilakukan pada ketika ini dalam tempoh penularan pandemik covid-19. Contohnya, dalam tempoh pandemik ketika ini, komponen luaran dan sub sistem kerajaan adalah pihak yang wajar bertindak balas untuk mengatasi dan mengawal ketidaktentuan keadaan sistem pengangkutan. Penilaian secara terperinci seperti pengumpulan data yang sesuai iaitu sifat setiap pemboleh ubah yang dikenal pasti iaitu komponen dan operasi sistem, saling ketergantungan antara pemboleh ubah yang lain dan kebarangkalian kesan terhadap langkah yang diambil adalah penting untuk proses resilien dilakukan. Setelah penilaian dilakukan maka proses perubahan dan penggunaan model resilien perlu dilaksanakan bagi memastikan proses resilien dalam sistem pengangkutan dapat dijalankan. 
Oleh itu, dapat disimpulkan bahawa ketahanan sistem pengangkutan adalah dinilai melalui ketahanan komponen dalaman dan luaran. Namun begitu, keadaan ini bergantung kepada keadaan persekitaran semasa yang mana ianya dapat dikawal secara keseluruhan mahupun sebaliknya. Jika tekanan daripada persekitaran terus meningkat dalam satu tempoh yang lama, maka penyesuaian sistem harus dilakukan dari masa ke semasa berdasarkan fenomena atau situasi sebenar.

\section{Dapatan}

Penularan Covid-19 yang berlaku di seluruh dunia mengakibatkan kesukaran perkhidmatan bas awam untuk beroperasi bukan sahaja di Malaysia malahan di seluruh dunia. Oleh itu, usaha dalam menangani masalah ini wajar dilakukan kerana sistem pengangkutan awam seperti bas awa, adalah pengangkutan yang penting untuk mobiliti penduduk di sesebuah negara (Saravanan et al., 2020). Lanjutan itu, seperti yang dinyatakan di dalam Rajah 4 setiap komponen dalam sistem pengangkutan adalah terlibat dalam proses resilien yang membolehkan sistem perkhidmatan bas awam dapat beroperasi dalam tempoh pandemik ini.

Rajah 4: Peranan Sub Sistem Dalam Resilen Perkhidmatan Pengangkutan Bas Awam

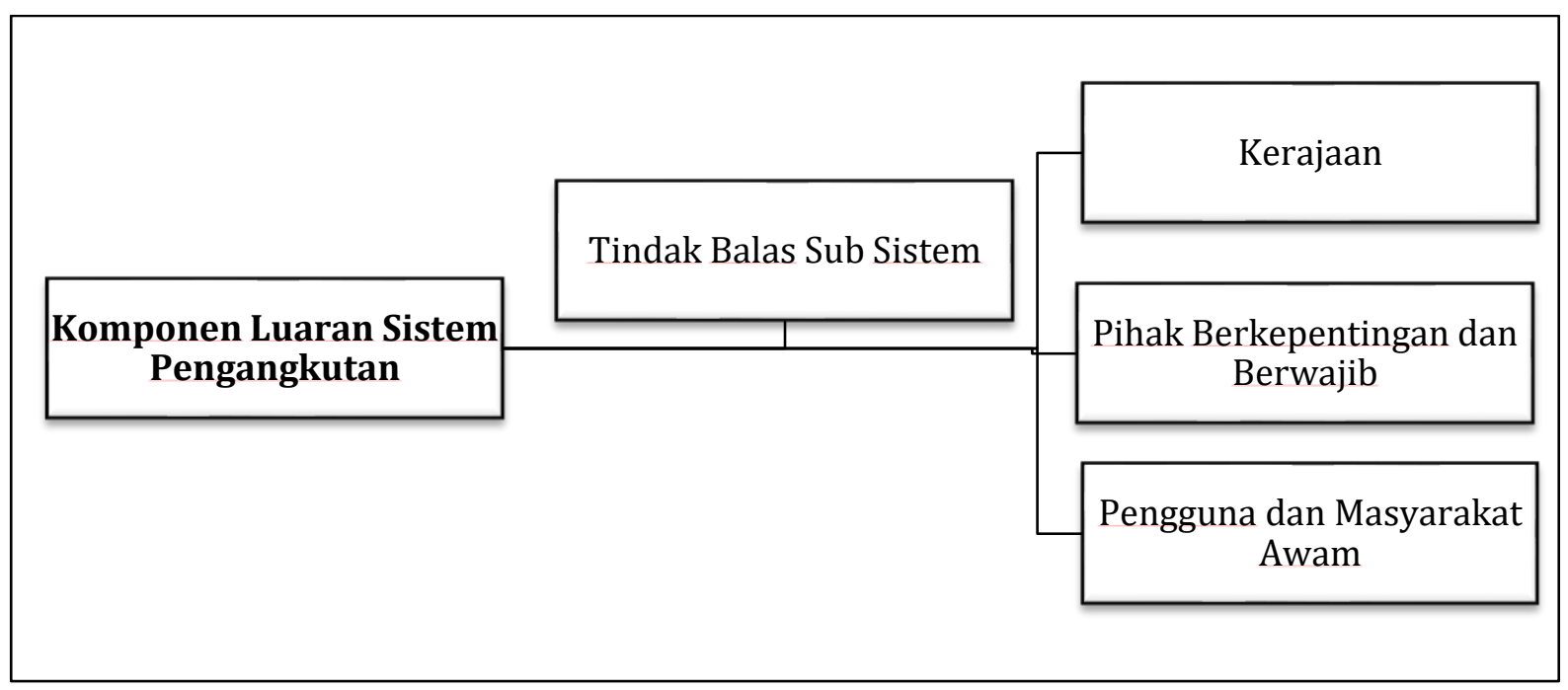

Sub sistem dalam komponen luaran iaitu kerajaan adalah memainkan peranan yang besar terhadap proses resilien sistem pengangkutan dalam era pandemik ini. Hal ini kerana, penyediaan polisi bagi sistem pengangkutan adalah tanggungjawab pihak kerajaan bagi memastikan perkhidmatan pengangkutan bas awam dapat beroperasi sekali gus tidak memberikan impak yang negatif terhadap syarikat, pemegang saham dan individu yang terlibat dalam industri pengangkutan. Penyediaan polisi seperti Prosedur Operasi (SOP) adalah aspek yang utama dalam proses resilien pengusaha bas awam. Polisi seperti penjarakan tempat duduk iaitu satu meter sehingga ke dua meter, penggunaan pembersih tangan (handsanitizer) penggunaan pelitup muka (mask) dan kapasiti penumpang yang dihadkan merupakan antara polisi yang diperkenalkan oleh kerajaan bagi membolehkan perkhidmatan bas awam terus dapat beroperasi dalam tempoh pandemik (Tirachini \& Cats, 2020). Polisi seperti ini bukan sahaja digunakan di Malaysia malahan di Eropah iaitu Netherlands, negara Amerika Selatan iaitu Chile dan negara-negara Afrika seperti Ghana turut mempraktikkan polisi yang sama (Dzisi \& Dei, 2020). 
Selain itu, perancangan strategi juga salah satu langkah sesuai yang perlu dilaksanakan bagi memastikan perkhidmatan bas awam terus dapat beroperasi ketika tempoh pandemik ini. Perancangan strategi yang dimaksudkan adalah melibatkan penutupan dan pembukaan stesen serta laluan bagi perkhidmatan ini (Gkiotsalitis \& Cats, 2021). Bagi mengelakkan penularan covid-19 dalam kalangan pengguna, pihak berkepentingan seharusnya mengambil langkah yang drastik dalam menentukan pembukaan atau penutupan stesen yang dianggap berisiko tinggi untuk digunakan. Dalam situasi pandemik ini, stesen dan laluan yang dianggap tidak relevan untuk digunakan seharusnya ditutup sementara (Gkiotsalitis \& Cats, 2021). Namun penutupan ini, seharusnya mengambil kira beberapa aspek tertentu seperti risiko kebolehjangkitan di stesen tersebut iaitu berkait rapat dengan luas sesebuah stesen, jumlah pengguna, dan kadar kes yang berlaku di kawasan berhampiran stesen tersebut. Melihat kepada langkah ini, ia sesuai untuk dipraktikkan kerana perancangan strategi ini membolehkan syarikat atau pengusaha perkhidmatan pengangkutan awam seperti bas awam dapat beroperasi dengan pengurangan kos operasi kerana tidak kesemua stesen dan laluan digunakan, walaupun mereka (pengusaha) tidak dapat memaksimumkan pendapatan dalam tempoh tersebut dan dalam masa yang sama penularan covid-19 dapat dielakkan.

Tambahan itu, perancangan taktikal adalah penting dalam era pandemik ini. Perancangan taktikal dalam sistem pengangkutan adalah seperti penentuan kekerapan dan masa perkhidmatan yang diberikan kepada pengguna dan orang awam. Perancangan taktikal ini sudah lama dipraktikkan dalam sistem pengangkutan seperti yang dinyatakan oleh Ceder (2002), penentuan kekerapan dan masa perkhidmatan adalah salah satu aspek yang penting untuk memastikan perkhidmatan yang diberikan sesuai dengan penggunaan oleh pelanggan serta dapat memaksimumkan pendapatan. Namun, dalam tempoh pandemik ini, penyesuaian haruslah dilakukan bagi mengurangkan risiko penularan virus covid-19 di kalangan pengguna dan orang awam. Seperti yang berlaku pada ketika ini, syarikat pengusaha atau pengendali perkhidmatan pengangkutan awam seperti kereta api dan bas telah mengurangkan frekuensi perkhidmatan mereka menjadi kurang daripada satu pertiga daripada frekuensi pra pandemik (Tan, 2020). Selain itu, melihat kepada situasi perkhidmatan pengangkutan awam di Malaysia berdasarkan laporan berita tempatan menyatakan bahawa, kerajaan Malaysia turut menetapkan masa perkhidmatan ini beroperasi iaitu dari pukul 6 pagi hingga 10 pagi dan 5 petang hingga 10 malam (Umavathi Ramayah, 2020). Perancangan taktikal ini adalah bertujuan untuk mengelakkan risiko jangkitan virus covid-19 yang tinggi dihadapi oleh pihak syarikat dan pengguna perkhidmatan ini.

Lanjutan itu, pengguna dan orang awam turut memainkan peranan yang penting dalam resilien sistem pengangkutan awam. Hal ini kerana, jika kerjasama daripada pengguna dan masyarakat awam tidak diperolehi maka segala perancangan yang dilakukan tidak dapat diaplikasikan atau dipraktikkan dalam situasi yang sebenar, sekali gus memberikan implikasi yang negatif dalam perkhidmatan pengangkutan awam. Menurut kajian Seres et al. (2021), pematuhan terhadap polisi penjarakan sosial dan pemakaian pelitup muka (mask) memberikan kesan terhadap kepercayaan orang ramai sama ada untuk berada di tempat awam dan berada dalam perkhidmatan pengangkutan awam. Kebolehpercayaan terhadap perkhidmatan merupakan ciri yang penting untuk pengangkutan awam untuk menghadapi tempoh pandemik ini. Hal ini kerana, jika pengguna dan orang awam tidak mempercayai bahawa pengangkutan awam boleh digunakan dalam tempoh pandemik, maka semua pihak yang terlibat dalam industri ini mengalami kerugian yang tinggi. Oleh itu, jelas bahawa bagaimana pengguna dan 
masyarakat awam turut memainkan peranan yang penting dalam resilien sistem perkhidmatan pengangkutan awam dalam tempoh pandemik ini.

Akhir sekali, pihak yang berwajib dan berkepentingan juga turut memainkan peranan yang sama dalam memastikan perkhidmatan pengangkutan awam terus beroperasi dalam tempoh pandemik ini. Pihak yang berkepentingan yang dimaksudkan adalah seperti pengusaha atau syarikat itu sendiri manakala bagi pihak berwajib pula adalah seperti Pihak Berkuasa Tempatan dan pihak berkuasa. Pengusaha atau syarikat yang memberikan perkhidmatan pengangkutan awam wajarlah mematuhi segala polisi yang dilaksanakan oleh pihak kerajaan agar penularan covid-19 tidak berlaku di kalangan pekerja, pengguna dan masyarakat awam. Dengan pematuhan polisi yang telah ditetapkan seperti penjarakan tempat duduk, penyediaan pengimbas suhu dan melakukan sanitasi terhadap kenderaan yang telah digunakan membolehkan perjalanan perkhidmatan dapat diteruskan tanpa memberikan risiko kepada semua pengguna perkhidmatan tersebut. Manakala, bagi pihak yang bertanggungjawab pula iaitu pihak berkuasa tempatan serta pihak berkuasa seperti Jabatan Pengangkutan Jalan seharusnya sentiasa melakukan pemeriksaan terhadap pematuhan polisi yang sudah ditetapkan. Pemeriksaan dan pemantauan yang kerap memainkan peranan yang tinggi terhadap pematuhan polisi bukan sahaja kepada pengusaha atau syarikat pengangkutan malahan kepada pengguna perkhidmatan itu sendiri.

Oleh itu, penggunaan model resilien dalam sistem pengangkutan adalah wajar dilakukan dalam sistem pengangkutan awam pada ketika ini. Model yang sesuai digunakan adalah model cabaran atau challenge model kerana faktor risiko adalah berkait rapat dengan impak yang diterima. Dalam sistem pengangkutan, penilaian risiko perlu dilakukan terlebih dahulu bagi memastikan impak yang positif dapat diperolehi. Oleh itu, komponen luaran iaitu kerajaan dan pihak pemberi perkhidmatan (syarikat) merupakan sub sistem yang memainkan peranan yang tinggi untuk menilai risiko dan implikasi setiap tindakan yang mereka lakukan.

\section{Kesimpulan}

Secara keseluruhannya, kemampuan ketahanan atau resilien perkhidmatan pengangkutan awam seperti bas awam mampu dilaksanakan jika penggunaan model resilien dapat diaplikasikan dalam situasi pandemik covid-19. Kebergantungan diantara komponen luaran dan dalaman dalam sistem pengangkutan awam adalah faktor utama pembentukan tindak balas yang penting dalam sistem reslilien pengangkutan pada ketika ini. Oleh itu, semua sub sistem dalam komponen sistem pengangkutan seperti kerajaan, syarikat dan pengguna merupakan sub sistem yang memainkan peranan yang besar lebih-lebih lagi dalam tempoh pandemik. Kebergantungan dan saling memberikan kekuatan serta berfungsi secara sistematik adalah aspek yang diperlukan dalam tempoh pandemik agar perkhidmatan pengangkutan iaitu bas awam terus dapat beroperasi agar impak penularan covid-19 tidak terlalu ketara seperti penurunan pendapatan atau kemasukan aliran tunai.

\section{Penghargaan (Acknowledgement)}

Terima kasih kepada semua pihak yang terlibat secara langsung dan tidak langsung dalam penulisan kajian ini. 


\section{Kewangan (Funding)}

Kajian dan penerbitan ini tidak menerima sebarang tajaan dan bantuan kewangan.

\section{Konflik Kepentingan (Conflict of Interests)}

Penulis tidak mempunyai konflik kepentingan.

\section{Rujukan}

Adger, W. N. (2000). Social and ecological resilience: Are they related? Progress in Human Geography, 24(3), 347-364. https://doi.org/10.1191\%2F030913200701540465

Ali, A. N. (2010). An Assessment of the Quality of Intra-urban Bus Services in the City of Enugu, Enugu State, Nigeria. Theoretical and Empirical Research in Urban Management, 5 (6 (15), 74-91.

Andaleeb, S., Haq, M., \& Ahmed, R. (2007). Reforming innercity bus transportation in a developing country: A passenger-driven model. Journal of Public Transportation, 10(1), 1-25. http://doi.org/10.5038/2375-0901.10.1.1

Ceder, A. (2002). Urban transit scheduling: Framework, review and examples. Journal of Urban Planning and Development, 128(4), 225-244. http://dx.doi.org/10.1061/(ASCE)0733-9488(2002)128:4(225)

Dekker, S., Hollnagel, E., Woods, D., \& Cook, R. (2008). Resilience engineering: New Directions for Measuring and Maintaining Safety in Complex Systems, Final report. Sweden: Lund University, School of Aviation.

Dzisi, E. K. J., \& Dei, O. A. (2020). Adherence to social distancing and wearing of masks within public transportation during the COVID 19 pandemic. Transportation Research Interdisciplinary Perspectives, (7). e100191. https://doi.org/10.1016/j.trip.2020.100191

Fatih Caniteza, Dilay Çelebi, Muhammet Devecib \& Yusuf Kuvvetli (2019). Selecting an optimal contractual payment model for Istanbul's public bus operators using nonlinear mathematical programming. Research in Transportation Economics, 76(1). http://dx.doi.org/10.1016/j.retrec.2019.100750

Fleming, J., \& Ledogar, R. J. (2008). Resilience, an Evolving Concept: A Review of Literature Relevant to Aboriginal Research. Pimatisiwin, 6(2), 7-23. https://www.ncbi.nlm.nih.gov/pmc/articles/PMC2956753/

Ganin, A. A., Kitsak, M., Marchese, D., Keisler, J. M., Seager, T., \& Linkov, I. (2017). Resilience and efficiency in transportation networks. Science Advances, 3(12), e1701079. http://dx.doi.org/10.1126/sciadv.1701079

Gkiotsalitis, K., \& Cats, D. (2021). Public Transport Planning Adaption Under The COVID19 Pandemic Crisis: Literature Review of Research Needs and Directions. $\begin{array}{lll}\text { Transport } \quad \text { Reviews, 374(3), 392. } & \text { 374- }\end{array}$ http://dx.doi.org/10.1080/01441647.2020.1857886

Harifah Mohd Noor, Mazdi Marzuki, Jabil Mapjabil, \& Oliver Valentine Eboy (2016). Keberkesanan perkhidmatan bas mini di Kota Kinabalu Sabah. Malaysia Journal of Society and Space, (12), 50-62. http://eprints.ums.edu.my/22168/

Hollnagel, E., Woods, D. D., \& Leveson, N. (2006). Resilience Engineering Concepts and Precepts. Ashgate Publishing, Ltd: Farnham.

Holling, C. S. (1973). Resilience and stability of ecological systems. Annual Review Ecological System, 4, 1-23. https://doi.org/10.1146/annurev.es.04.110173.000245 
Juan Pablo Sepúlveda \& Patricia Galilea (2020). How do different payment schemes to operators affect public transport concessions? A microeconomic model. Transport Policy, 93, 27-35. https://doi.org/10.1016/j.tranpol.2020.04.016

Kenneth, D. B. (1990). Social Entropy Theory. State University of New York Press.

Keye, M. D., \& Pidgeon, A. M. (2013). An Investigation of the Relationship between Resilience, Mindfulness, and Academic Self-Efficacy. Open Journal of Social Sciences, 1(6), 1-4. http://dx.doi.org/10.4236/jss.2013.16001

Ledesma, J. (2014). Conceptual Frameworks and Research Models on Resilience in Leadership. SAGE Open Journal, 4(3). https://doi.org/10.1177\%2F2158244014545464

Litman, T. (2010). Evaluating public transit benefits and costs: Best Practices Guidebook. Victoria Transport Policy Instutute. https://www.vtpi.org/tranben.pdf

McTigue, C., Monios, J., \& Rye, T. (2020). The principal-agent problem in contracting public transport provision to private operators: A case study of the UK Quality Contract Scheme. Utilities Policy, 67. e101131. https://doi.org/10.1016/j.jup.2020.101131

Mohit Dev \& Arindam Biswas. (2020). Studying Operational Dynamics of Public Bus System: A Case of Lucknow City, India. Transportation Research Procedia, 48(6), 3211-3222. http://dx.doi.org/10.1016/j.trpro.2020.08.159

Molloy, J., Tchervenkov, C., Schatzmann, T., Schoeman, B., Hintermann, B., \& Axhausen, K. W. (2020). MOBIS-COVID19/08: Results as of 25/05/2020 (post-lockdown). Arbeitsberichte Verkehrs- und Raumplanung, 1506, IVT, ETH Zurich. https://doi.org/10.3929/ethz-b-000416869

Nemeth, C. P. (2008). Resilience Engineering Perspectives, Volume 1: Remaining Sensitive to the Possibility of Failure ( $1^{\text {st }}$ ed.). CRC Press.

Noraini Omar Chong, Khairul Hisyam Kamarudin \& Siti Nurhuda Abd Wahid (2018). Framework Considerations for Community Resilient Towards Disaster in Malaysia. Procedia Engineering, 212, 165-172. http://dx.doi.org/10.1016/j.proeng.2018.01.022

O'Leary, V. E. (1998). Strength in the face of adversity: Individual and social thriving. Journal of Social Issues, 54(2), 425-446. http://dx.doi.org/10.1111/j.15404560.1998.tb01228.x

Prasad, B. D. (2008). Content analysis: A method in Social Science Research, In D.K. Lal Das (Eds.), Research Methods for Social Work, (pp. 174-193). Rawat Publications. http://dx.doi.org/10.13140/RG.2.1.1748.1448

Roy, W., \& Yvrande-Billon A. (2007). Ownership, Contractual Practices Technical Efficiency. The Case of Urban Public Transport in France. Journal of Transport Economics and Policy, 41(2), 257-282.

Sabitha Marican. (2009). Penyelidikan Sains Sosial: Pendekatan Pragmatik. Edusystem. Sdn. Bhd.

Saravanan Sundara Sakaran, Harifah Mohd Noor \& Rosmiza M. Z. (2020). Ketersampaian penduduk terhadap perkhidmatan pengangkutan awam di Bandaraya Kota Kinabalu, Sabah. Malaysian Journal of Society and Space, 16(1), 168-181. http://dx.doi.org/10.17576/geo-2020-1601-13

Seres, G., Balleyer, A. H., Cerutti, N., Danilov, A., Friedrichsen, J., Yiming Liu, \& Süer, M. (2021). Face masks increase compliance with physical distancing recommendations during the COVID-19 pandemic. Journal of the Economic Science Association, 7, 139-158. http://dx.doi.org/10.1007/s40881-021-00108-6

Tamvakis, P., \& Xenidis, Y. (2012). Resilience in transportation systems. Social and

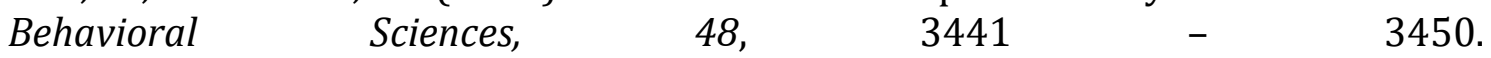
https://doi.org/10.1016/j.sbspro.2012.06.1308 
Tan, C. (2020 May, 30). Coronavirus: Reduced frequency of trains leads to crowding on some.

The Stratis

Time. https://www.straitstimes.com/singapore/transport/reduced-frequency-of-trainsleads-to-crowding-on-some

Taylor, B. D., \& Fink, C. N. Y. (2013). Explaining transit ridership: What has the evidence shown?. The International Journal of Transportation Research, 5(1), 15-26. http://dx.doi.org/10.1179/1942786712Z.0000000003

Tirachini, A., \& Cats, D. (2020). COVID-19 and Public Transportation: Current Assessment, Prospects, and Research Needs. Journal of Public Transportation, 22(1). http://dx.doi.org/10.5038/2375-0901.22.1.1

Turner, S. B. (2014). The Resilient Nurse: An Emerging Concept. Nurse Leader, 12(6), 7173. http://dx.doi.org/10.1016/j.mnl.2014.03.013

Umavathi Ramayah. (2020 Mac, 23). Operasi pengangkutan awam 6-10 pagi, 5 petang10 malam-Ismail Sabri. Astro Awani. https://www.astroawani.com/beritamalaysia/operasi-pengangkutan-awam-6-10-pagi-5-petang10-malam-ismailsabri-234882.

Werner, E. E., \& Smith, R. S. (2001). Journeys from Childhood to Midlife: Risk Resilience and Recovery. Cornell University Press.

Zhang, W. J., \& Lin, Y. (2010). On the principle of design of resilient systems-Application to enterprise information systems. Enterprise Infomation System, 4(2), 99-110. http://dx.doi.org/10.1080/17517571003763380

Zhang, W. J., \& Van, L. C. A. (2011). Toward a resilient manufacturing system. CRIP Annals- Manufacturing Technology, 60(1), 469-472. http://dx.doi.org/10.1016/j.cirp.2011.03.041

Zhu, H., Wei, L., \& Niu, P. (2020). The novel coronavirus outbreak in Wuhan, China. Global Health Research and Policy Journal, 5(1). http://dx.doi.org/10.1186/s41256-020-00135-6 